\title{
Maria Pijevac
}

E-mail: pijevac@pfri.hr

Edvard Tijan

E-mail: etijan@pfri.hr

\section{Mladen Jardas}

E-mail: mjardas@pfri.hr

University of Rijeka, Faculty of Maritime Studies, Studentska 2, 51000 Rijeka, Croatia

\section{Facilitating Seafarers Employment Using a Common Database}

\begin{abstract}
Summary
A key part of the maritime crewing agent business is the employment of seafarers (apart from drafting contracts between ship owners and seafarers), finding suitable personnel to fill the job vacancies advertised by ship owners. Maritime crewing agencies generally keep records of seafarers in their own databases. However, those databases often happen to fall short of the requested professionals (officers) and/or the support staff. In such cases, agencies spend a lot of time on finding the personnel possessed of the required qualifications and experience. This paper researches the positive and negative sides of a common database of seafarers, their meaningfulness or drawbacks, and the attitudes of maritime crewing agencies relating to common databases. A survey was conducted among Croatian maritime crewing agencies in order to obtain information on their operations and opinions concerning the proposed common seafarer database.
\end{abstract}

Keywords: databases, seafarers, maritime crewing agents, seafarer documents

\section{Introduction}

Maritime crewing agencies as mediators in employment of seafarers spend significant amounts of time to find the appropriate staff meeting the desired criteria for the vacancies advertised by the ship owners. The aim of this paper is to explore the positive and negative sides of a common database of all crewing agencies operating in Croatia. Such a database would facilitate crewing agents' internal procedures by allowing for faster and easier search of seafarers and other support staff on board and, on the other hand, it would simplify the employment process itself. The basic features of the respective database would be simplicity and availability of maritime professionals. 
There are many aggravating circumstances affecting the work of maritime crewing agencies on finding the staff required by shipping companies. One of the problems is the limited time that the agents have to find a suitable seafarer, which is usually short due to the nature of navigation. In order to ensure their business continuity, shipping companies must provide smooth and continuous navigation of ships. One of the conditions to be met for continuous and safe navigation is the prescribed number of crewmembers and a quality staff selecting process. Agencies are therefore obliged to provide shipping companies with crew members of quality, possessed of the necessary titles and professional qualifications in order for the ship not to be left short of any necessary crewmembers, as this would hinder navigation and potentially create financial loss to the shipping company. The necessary changes of the on-board personnel are mostly predictable on the basis of signed contracts, yet emergencies often occur due to unforeseeable circumstances (illness, neglected labour relations, etc.) and make it necessary for the replacement to be found quickly (a person with necessary maritime education and experience).

By means of the new applications, a common database for all crewing agencies should be established that would contain all the necessary information on seafarers. The suggested database would store any relevant information and documents concerning seafarers and would enable selection of seafarers according to their education, working experience, employment status etc. in order to facilitate the work of maritime crewing agencies in finding the desired staff. Both sides, i.e. the crewing agencies as mediators in the employment of seafarers, and seafarers whose information would be stored in the database, would have access to the database according to their preferences, needs and authorizations.

Furthermore, the paper explores the business procedures currently used by crewing agencies: the way they search for suitable candidates, what type of personnel they employ, the number of employed seafarers on a yearly basis, etc. In order to find out whether a common database for shipping agencies is necessary at all, a survey was conducted about databases kept by individual agencies and a research of their attitudes about a common database was carried out. In addition, the documents were explored that would form the mentioned database: seafarers' certificates of basic competencies, seaman's book, boarding permission, identity documents of seafarers and other personal data. Databases store data, facilitate business procedures, enable faster and easier communication, and enable data search and analysis. Consequently, the research was aimed at showing that the creation of a common database of seafarers is one of the preconditions for the improvement of crewing agencies business procedures.

\section{Certificates and documents of seafarers}

Like any other business sector, the maritime sector must respect the legislation and rules governing employee qualifications. Therefore, the Croatian Ministry of Maritime Affairs, Transport and Infrastructure has passed the Ordinance on Vocations and 
Certificates of Competencies for Seafarers [15]. The Ordinance outlines the vocations, qualifications, test programs, training programs, conditions and practice concerning the acquisition of certificates of competencies (basic and additional ones) for masters, officers and other crew members. It also outlines the rules and conditions for the recognition, renewal, replacement and revocation of certificates, etc.

Certificates serve to evidence the qualification possessed by a seafarer to perform various marine activities of specific duties and levels of responsibility, with possible restrictions, international labels and expiry date. Furthermore, the certificates can be classified into certificates of basic competencies (Certificates of Equivalent Competency) and certificates of additional competencies. Some are compulsory (e.g. Basic Safety Training) and some are ship dependent.

Certificates of basic competencies have the same name as the profession on board itself. Such certificate shows the position (or positions) aboard the ship the seafarer may hold. Certificates for the same title vary in dependence on vessel's size or type. It is important for them to show the expiry date as well which can indicate how often the mentioned databases need to be updated regarding the seafarer. The expiry date is five years from the date of issue, except for the certificates without time limit.

Certificates of additional competencies mostly relate to the safety of navigation. Certain certificates of additional competencies are compulsory, while the possession of others depend on the type of ship (tankers, passenger ships, etc.). Sometimes the acquisition of a certificate depends on the shipping company or the shipping agent who represents the shipping company.

In addition to the above certificates of competencies, seafarers must possess several documents that are needed for successful employment on board. These documents provide more safety for seafarers, contain their identity data, allow international navigation etc. These documents contain a certificate of competence of seafarers, their health status and other seafarers' details. The mentioned documents are seaman's book, boarding permission, identification document and medical certificate, which will be explained later. Other documents found in the crewing agencies' databases will also be mentioned.

Seaman's book shows the identity, the rank (qualification) under which the holder of the seaman's book boarded, the duration of navigation service, medical fitness and professional competence [13]. The issuance of seaman's book is preconditioned by the Basic Safety Training Certificate and a valid medical certificate.

The embarkation permit proves the identity, the qualification of the holder, the duration of navigation service on maritime vessels registered in the corresponding registers, medical fitness and professional competence [13].

The seafarer's identification document proves the identity of the crewmember [13]. The identification document for seafarers is not a compulsory document. The document allows the seafarers certain rights and facilitates their travel to other countries for boarding, as well as their landing within the limits of the city where the ship is. The purpose of this is to increase the security measures for the protection of seafarers. 
The above documents (seaman's book, embarkation permit and seafarer's identification document) are issued by the Harbourmasters office with a validity period of 10 years. These identification documents mostly contain repetitive data, except for the seaman's book and the embarkation permit, which are more detailed. They contain information about medical examinations, blood group, Rhesus factor, hypersensitivity to medication, serums and vaccines, as well as the embarkation and disembarkation data, which the identification document does not contain. The larger size of seaman's book and embarkation permit is justified because they are compulsory documents, unlike the identification document.

Medical certificate confirms that the person is able to work, and that he can perform physical tasks required by the maritime professions [2].

Several other seafarer documents can also be found in crewing agents' databases: passports, visas, dental cards, vaccination certificates, D \& A Tests (Drug and alcohol testing), $\mathrm{CB}$ tests and Panamanian licenses.

\section{Agents that mediate the employment of seafarers}

Crewing agencies have an important role in the maritime business and it is almost impossible to imagine the optimal functioning of the maritime transport without the active participation of crewing agents. During the employing process, crewing agents are contract mediators between ship owners and seafarers.

The mediator (agent) in possession of a valid license can perform employment mediation for seafarers. The Ministry of Maritime Affairs, Transport and Infrastructure (with the prior opinion of the Commission) issues the license. The license is awarded to the legal entity registered in Croatia to provide employment mediation services according to the national classification [12]. Conventions and agreements relating to agents specialized in employment mediation services will be mentioned in the text to follow.

Recruitment and Placement of Seafarers Convention, 1996 was adopted at the 84th Conference of the International Labour Organization. The convention regulates the issues on employment mediation for seafarers, the method of authorizing legal entities engaged in the employment mediation services for seafarers, the control over such legal entities, their duties and responsibilities. The Convention includes all categories of seafarers and all persons employed on board [1]. The Convention allows the liberalization of employment mediation services for seafarers, while respecting strictly prescribed conditions for an easier access of seafarers to the world labour market with the protection of their rights.

The Maritime Labour Convention [10] is extremely important for all agents involved in the employment mediation services for seafarers because it contains all rules governing the work and employment of seafarers. The principle is similar to the aforementioned Convention, but the Maritime Labour Convention covers almost all aspects of life and work of seafarers. The Act on ratification of the Maritime Labour 
Convention of 2006 was adopted in Croatia in late 2009. The aim of the Convention is to include all the latest standards of the existing conventions [16] [17] [18] [19] [20] [23] [24] [25] and recommendations on the international labour of seafarers. Each state that has ratified the Convention is obliged to contribute to the full effect of its regulations in order to ensure the right to decent employment to all seafarers [2].

The most important part of the Convention for crewing agents is the recruitment and employment of seafarers. The purpose is to ensure access to a reliable and wellregulated system of recruitment and employment of seafarers. Companies which recruit and employ seafarers, or crewing agencies in the Republic of Croatia, must obey the standards laid down in the Convention, whether they are public or private services.

One of the most important regulations prescribed by this Convention and related to this paper is that the competent authority shall consider the right to privacy and the need to protect confidentiality of the crewing agencies, and the conditions under which the crewing agencies can handle seafarer personal data (including the collection, storage, forming and forwarding of such data to third parties) [2]. According to this regulation, it can be concluded that the agencies do not necessarily have to share their data to a common database of the crewing agencies, but can keep the information about seafarers for themselves. However, they should allow the competent authorities access to complete and comprehensive records of seafarers referring to the system of recruitment and hiring, which should include seafarers' qualifications, employment records, personal information about employment and medical data relevant to employment (in order that the competent authorities could perform the control of crewing agencies). Agencies are also obliged to keep updated the list of ships for which they provide seafarers, publish their costs etc.

Maritime work contract is signed between the ship-owner or his representative and the seafarer. After signing the contract, the seafarer must be given a document containing the information about his employment on board the vessel. This document should not contain any evaluation of the quality of the seafarer's work or data about his salary. The seafarer may ask the master a special certificate about the quality of his work, which states whether he has fulfilled all the obligations of the contract.

In 2015, 42 shipping agencies were operating in the Croatian territory as legal entities licensed to negotiate the employment of seafarers, or licensed to work as crewing agencies [22]. According to a short survey conducted on a website, which provides an overview of Croatian companies certified according to the ISO 9001 [21], it can be concluded that the majority of crewing agencies in the Republic of Croatia apply quality standards, because $69 \%$ of these maritime agencies are ISO 9001 certified.

It is also important to mention the Croatian Ship Manning Association (CROSMA), a non-profit entity that promotes maritime occupations and makes the quality link between seafarers and employers in Croatia. It is an association of crewing/manning agencies that mediate the employment of seafarers in the Republic of Croatia, which is a member of the Eurocrew initiative [3] (to share common ideas appearing among various institutions and individuals deeply involved in the maritime human 
resources sector, coming from Croatia, Latvia, Poland, Romania and Slovakia). Agents in the association exchange their experience, promote and protect their interests and rights in order to protect the interests of seafarers in relation to the interests of their employers. All this is done in accordance with the internationally recognized maritime regulations and national legislation. Members are employing thousands of seafarers, reducing unemployment and thus greatly contributing to the development of the Croatian maritime industry and the economy as a whole [5]. According to that, CROSMA could have an important role in the design and implementation of a common seafarer database in Croatia.

\section{Seafarer database}

In the following text, the current crewing agencies database management will be studied and an improvement of the database with the documentation of seafarers will be proposed. The purpose of the proposed database is to facilitate the business of crewing agencies in terms of faster and easier finding of the desired staff for boarding. Through this database, seafarers would also have the possibility to find an adequate employment in an easier manner, because the crewing agencies would, if they wish so, advertise their job openings. The proposed role of harbour master office in maintaining and populating the common database will be elaborated.

\subsection{Current seafarer database management}

As stated above, according to the Maritime Labour Convention, crewing agencies have the right to privacy and the protection of secrecy, including the collection, storage, forming and forwarding of seafarer personal information, which leads to the fact that crewing agencies generally possess their own databases, which they rarely share with other agencies.

Because of their independent acting on the market, crewing agencies in fact compete against each other. Accordingly, the volume and quality of their database can provide a competitive advantage in agency's business. Consequently, it can be assumed that the agencies would not want to have a shared database. However, the existing private database (Maritime Connector) is used by many crewing agencies, companies and seafarers, which have thus facilitated their business.

The private Maritime Connector database was formed in 2007. Seafarers and registered crewing agencies, companies or ship owners can register and use the database. Maritime Connector is actually a web portal designed as a place where seafarers, crewing agents, maritime education centres, maritime colleges and other institutions can easily communicate. The purpose is to find the desired staff faster and to provide ship owners and agents with a database that stores records of a large number of seafarers and other personnel in the maritime industry, thus facilitating the business of 
crewing agencies involved in the employment mediation for seafarers. The purpose is also to provide the latest information to seafarers about the required education, job offers, amendments to basic and additional training and other rules, to display the latest announcements of shipping companies, etc. [4].

Maritime Connector manages the database, but also allows an independent entry of seafarer data through its website. Seafarers can also update their data and thus enter the most recent documents about their qualifications, certificates etc. By storing documents, a seafarer is recorded in the database, which can later be searched by crewing agencies looking for new job candidates. This enables the seafarers to find work in an easier manner, and crewing agencies to find the desired candidates more quickly. Registration is free for seafarers, whereas crewing agencies are required to pay a fee when selecting each seafarer from the database (enabling Maritime Connector to earn income). Maritime Connector has helped in the past nine years a large number of international companies, and today it is the largest community of professional seafarers [4].

All Croatian seafarers are included in the system of health and retirement insurance, regardless of the flag they are sailing under, and regardless of their employer nationality. Harbourmaster offices and authorized agents must participate in the inclusion of seafarers (the check-in and check-out) in the compulsory health and retirement insurance database. Croatian employers have the obligation to directly register their seafarers in the compulsory database.

For those Croatian seafarers who up to now have been included in the compulsory health and retirement insurance database, the competent port authority will submit the check-in and check-out registrations for the proposed common database for crew members serving on internationally owned ships (employer is a foreign legal entity, if the seafarer is the Croatian resident [11]. According to the latest changes to the Maritime Code, all Croatian seafarers (estimated around 22000 [8]) are included in the health and retirement insurance scheme, regardless of whether they are sailing under the domestic or foreign flag.

\subsection{Improving databases in order to facilitate the employment of seafarers}

In the future development of common seafarer databases, efforts should be aimed towards creating a database that would store the data and documents of all Croatian seafarers. This would additionally raise the level of efficiency of maritime agencies and avoid possible navigation bottlenecks due to the lack of adequate staff. As already mentioned, each agency has a more or less elaborated database and is probably not willing to share it with other agencies because of the competitiveness among the agencies. However, due to the market needs, it often happens that certain agency at some moment does not have adequate staff for the ship owners in its own database. Therefore, it is justified to research and evaluate the purpose of a common database of all professions that are needed in the maritime industry. 
The further improvement of the common seafarer database would be the connection between the aforementioned systems, the Maritime Connector and the health and retirement insurance scheme. The proposed common database would operate at the national level, where data and documents of all seafarers resident in Croatia would be stored. The principle of the database would be based on the Maritime Connector database (storage of seafarer data searchable by crewing agencies). Seafarers would be obliged to report to the competent harbourmaster office, and thus would be registered in the database, similar to the health and retirement insurance scheme database principle. This means that the Croatian authorities would maintain the database, and crewing agencies would be able to enter certain types of information about seafarers. Seafarers who would be included in the database could be divided in several groups (for example "employed", seeking employment", "on sick leave", "currently not seeking employment", etc).

According to the law, every seafarer is obliged to report to the competent harbour master office. The harbour master office issues seaman's books, determines the professional competence of seafarers to acquire maritime professions, and maintains the register of issued competencies for services aboard ships [6]. The harbour master office, as well as crewing agencies, registers the seafarers in the Offices of health and retirement insurance. Considering the common obligations of the harbour master office and the crewing agencies, it is very easy to add the obligation of registering (storing) seafarers' data in the proposed common database. The common database would contain seafarer documents, and the documents would be saved by the harbour master office with the participation of crewing agencies.

When issuing the seaman's book and the embarkation permit, the duty of harbour master office would be to enter the data into the common database, as well as any other documents submitted personally by the seafarers. At the same time, the validity of the necessary documentation and its correctness would be checked. Respectively, only the valid documents would be entered into the database. It is clear that the documents with questionable accuracy would not be saved. This would ensure that the crewing agencies always have the correct documents of seafarers. Crewing agencies could also actively participate by evaluating their experience with seafarers (e.g. using the grading scale of 1 to 5 or similar), which would probably facilitate the selection by other agencies. Of course, such grading system should be carefully devised, evaluated and approved.

When implementing a common database, the development and maintenance costs should be estimated carefully. The common database should be accessible via the standardized web forms, which would simplify the use and eliminate the need for specialized ICT equipment. When initially populating the proposed common database, harbour master offices (as opposed to the Maritime Connector) would not charge either the seafarers or the crewing agencies for the data collected, since the seafarers (according to the MLC Convention) must have access to an appropriate (and free of charge) system for finding employment on board. After the database and the respective applications are programmed and populated, its users would be the crewing agencies that mediate 
the employment of seafarers and the seafarers themselves, and its administrators would be the competent harbour master offices. The cost of using the common database, for both the seafarers and the crewing agencies would then have to be determined. That revenue would be used for maintaining the common database. Several revenue models could be implemented (ranging from full government funding to individual charging of crewing agencies), but that would be the topic for a future research.

\section{Survey results - the use of database in seafarer employment}

To confirm the need for further development of a common database of seafarers, a research was carried out by performing a survey, and the results of the survey provided a framework on the attitude of crewing agencies involved in the employment mediation for seafarers on the usefulness of the development and integration of common databases. A survey was conducted among the crewing agencies licensed for employment mediation for seafarers in the Republic of Croatia and listed on the Ministry of Maritime Affairs, Transport and Infrastructure website [7].

In total, 42 shipping agencies were contacted, and 17 of them responded (roughly $40 \%$ ). Out of 17 agencies that submitted responses, 12 were small (1-10 employees) and five were medium sized (11-50 employees). Such result was expected considering that smaller crewing agencies are predominant in Croatia. Four agencies have been operating for less than five years, five agencies between five to 15 years, and four agencies for more than 15 years.

Out of 17 surveyed agencies, 15 of them are solely in the business of seafarer employment mediation. Employees from 13 agencies are fluent in English language (high level), and employees from four agencies are able to use the English language independently (medium level), which indicates the importance of communication in a foreign language, because agency business implies finding and contacting international carriers.

By analyzing the number of seafarers employed via the crewing agency on a yearly basis, the following results were obtained: only one agency employs up to 20 seafarers per year, while other agencies have a larger business volume. Four agencies employ 20-50 seafarers annually, five agencies employ 50-200 seafarers annually, four agencies employ 200-500 seafarers annually, and three agencies employ more than 500 seafarers annually.

Bulk carriers are the type of ships with most seafarers employed by crewing agencies (10 agencies), followed by tankers ( 9 agencies), container ships ( 6 agencies) and other types of ships (cruisers, offshore, etc.). Eight agencies employ all categories of seafarers, and 7 agencies employ only officers. No agency employs support staff only. This information is very useful because in the first step, the common database would contain ship officers' documentation only. After a while, it would expand its scope to other staff. According to the survey, the common database containing ship officers' data would be useful for the majority of crewing agencies. 
$47 \%$ of crewing agencies often find themselves in a situation where adequate staff cannot be found (several times a year), and $24 \%$ of agencies find themselves in such a situation several times per month. No agency responded to have been always able to find adequate staff, which means that agencies might be open to alternative solutions for recruiting seafarers.

Crewing agencies generally consider having sufficient information and documentation about the seafarers stored in their own databases, so they rarely resort to other means of recruiting seafarers (13 of 17 respondents). However, if they do not find the required staff in their databases, the agencies publish a notice of demand on their publicly available websites ( 9 interviewed agencies). Furthermore, five agencies will seek help from other agencies.

The interviewed were asked to indicate the method of storing documentation of seafarers, and they chose only two answers: "Custom application" ( $82 \%$ of agencies) and "Other computer programs" (18\% of agencies). The advantage of searchable custom applications proved to be an important tool and a competitive element among crewing agencies.

When asked, "Do you share information about your seafarers with other shipping agencies", it turned out that most agencies keep their data on seafarers for themselves, or share it rarely. Only four out of 17 agencies often share their data with other crewing agents (all of them are small agencies, and 75\% have been less than five years in the seafarer employment market). It can be assumed that they are not sufficiently positioned on the market yet and by sharing data, they facilitate their mutual business. This information also shows the potential of a common database as an important element of competitiveness among smaller, not yet established agencies. Larger agencies would probably use the common database only after having exhausted their own significant resources.

The research has shown that only one agency has not heard of the Maritime Connector, a private database. More than one half of the surveyed agencies think that Maritime Connector is useful in the employment of seafarers, which justifies the suggestions for further improvement and development of the common database. Still, most agencies (65\%) do not use Maritime Connector. All agencies that responded accordingly also responded that they already have their own adequate database. However, that answer was also chosen by agencies that use Maritime Connector, which means that even with their own developed databases, agencies are sometimes found in a situation where they cannot find the required staff (and therefore they sometimes use the Maritime Connector services). The answer to this question confirms the potential for further development of a common database.

Most agencies believe that there is no need for a common database that would store documentation of seafarers. They stated that the main obstacle of introducing a common database would be competition among agencies, where often one agency would recruit people from other agencies. Furthermore, given the relatively small size of Croatia, they believe that the information is easily accessible to seafarers and 
that it is not hard to find an agency that mediates employment on ships for which the seafarer is specialized. One of the respondents feels that national authorities should have a website that would publish the demand for seafarers on a daily basis (based on the input from crewing agencies). Thus, the seafarers could have better insight in the type of jobs being offered by crewing agencies in Croatia. Several respondents state that databases are private property of each agency which is not willing to share them with other agencies. Of course, agencies that stressed the previously mentioned comment responded that they never share their information with other agencies. From this response, it can be concluded that a quality common seafarer database is one of the crucial elements of competitiveness.

Eleven agencies (64.7\%) would use a common database only if it would be free of charge, and six agencies (35.3\%) would not use it in either case. The majority of agencies stated they would use the database if it would be adapted to their needs. Some responses were very positive, for example: "Of course a joint database would facilitate the work of crewing agencies, agencies would use it gladly". Other comments were negative, for example: "Information about seafarers represents the commercial property of the agency, and property should not be shared". One crewing agency responded that they would use the database to verify the accuracy of CVs and other documents of seafarers. Crewing agencies would generally use a common database only if free of charge.

\section{Conclusion}

The paper explores the idea and proposes a concept of a common database at a national level in order to facilitate the employment of seafarers. The necessary documents for the employment of seafarers on board were mentioned which must be provided to crewing agents who mediate between ship owners and seafarers, and who conclude employment contracts with the seafarers on behalf of ship owners. These documents should be stored in the mentioned database.

Crewing agents that mediate the employment of seafarers have limited time in which they must find a suitable seafarer for a certain vessel. Agencies generally store seafarer documents in their own databases, which contain detailed information about every seafarer. However, the research shows that most agencies are often found in a situation where they cannot find a seafarer with adequate education, knowledge and experience for employment for a particular position aboard the vessel.

It was through a survey that opinions of crewing agencies were examined regarding a common database, which would store the documentation of seafarers resident in the Republic of Croatia. The results of the research showed that crewing agencies are interested in using a common database free of charge. If they had to pay for it, its use would be reduced because of the existing well-developed individual databases owned by the agencies themselves. 
Responsible harbour master offices would maintain the mentioned common database. Harbour master offices are obliged to report seafarers to the system of health and retirement insurance. Thus, they already have a database that stores seafarer information, but only basic information (their sailing time and salary). Harbour master offices also issue seaman's books, embarkation permits, identification documents and define the professional qualification of seafarers.

Beside all the duties of harbour master offices, it is proposed for them to administer a database that would store all documents issued to seafarers at a national level. In addition, it is proposed that the database should also include any other documents that are necessary for the employment on board, as well as any personal information on an individual and working experience of every single seafarer at certain levels of responsibility on board. Therefore, seafarers should submit all documents that they have to their harbour master offices in order to facilitate the search by crewing agents and thus to increase the possibility of their employment. On the other hand, crewing agencies themselves could participate in the storage of information. They would evaluate the work of seafarers in order to facilitate the selection of seafarers for other maritime agencies. Of course, one should take into account the subjectivity during the evaluation.

By having the common database used by agencies, its value and efficiency would be increased. In that regard, the seafarers seeking employment would aim to be included in the common database in order to increase their possibility of employment Therefore it would be easier for relevant institutions to control the work of seafarers, mainly their registration to the compulsory health and retirement insurance scheme.

The precondition for the proposed common database is to develop a high-quality software and hardware solution that will allow quick and easy storage and searching of data (web based). Furthermore, effort should be put into the education of harbour master office employees.

Intelligent database management systems undoubtedly facilitate business processes, enable faster and simpler communication between seafarers and maritime agencies and optimize searching and querying. Some agencies are opposed to the idea of a common database because they believe that such a database would jeopardize their competitive advantage over other agencies. Surely, there are other ways of achieving competitive advantage on the market, apart from hiding information about seafarers. Crewing agencies should be presented with equal opportunities on the market, and they should be enabled to have the same information on seafarers. 


\section{References}

1. Act on ratification of the Recruitment and Placement of Seafarers Convention (Official Gazette 41/2001)

2. Act on the ratification of the Maritime Labour Convention (Official Gazette 11/2009)

3. http://eurocrew.org/ (10.08.2016.)

4. http://maritime-connector.com/about-us/ (18.08.2016.)

5. http://www.crosma.hr/en/info/about-us (10.08.2016.)

6. http://www.mppi.hr/default.aspx?id=475 (12.08.2016.)

7. http://www.mppi.hr/default.aspx?id=6148 (23.08.2016.)

8. http://www.mppi.hr/default.aspx?id=9468 (15.08.2016.)

9. Maritime Code (Official Gazette 181/2004)

10. Maritime Labour Convention, Geneva, 2006

11. Ministry of Maritime Affairs, Transport and Infrastructure: Information regarding the seafarer social security reform, 2007

12. Ordinance on recruitment and placement of seafarers (Official Gazette 120/2007)

13. Ordinance on seaman's books and embarkation permits, procedures and mode of registration and deregistration of seamen in the compulsory pension insurance scheme and the compulsory health insurance scheme (Official Gazette 54/2013)

14. Ordinance on the conditions for the shipping agent business, and the rights and obligations of the ship agent (Official Gazette 82/2007)

15. Ordinance on Vocations and Certificates of Competencies for Seafarers, Official Gazette 130/13, $45 / 14$

16. Convention concerning the Abolition of Forced Labour, Geneva, 1957 (No. 105)

17. Convention concerning Discrimination in Respect of Employment and Occupation, Geneva, 1958 (No. 111)

18. The Equal Remuneration Convention, Geneva, 1951 (No. 100)

19. Convention concerning Forced or Compulsory Labour, Geneva, 1930 (No. 29)

20. Convention concerning Freedom of Association and Protection of the Right to Organise, San Francisco, 1948 (No. 87)

21. The list of companies certified according to ISO 9001: http://www.kvaliteta.net/kvaliteta/9certifikati. aspx (19.08.2016.)

22. The list of legal entities authorized according to the Ordinance on recruitment and placement of seafarers (Official Gazette 120/2007)

23. Convention concerning Minimum Age for Admission to Employment, Geneva, 1973 (No. 138)

24. Convention concerning the Application of the Principles of the Right to Organise and to Bargain Collectively, Geneva, 1949 (No. 98)

25. Convention concerning the Prohibition and Immediate Action for the Elimination of the Worst Forms of Child Labour, Geneva, 1999 (No. 182) 


\section{Zapošljavanje pomoraca korištenjem zajedničke baze podataka}

\section{Sažetak}

Ključni dio poslovanja agencija koje posreduju pri zapošljavanju pomoraca, osim sklapanja ugovora između brodara i pomoraca, čini i pronalazak kadra potrebnog brodarima. Agencije za posredovanje pri zapošljavanju pomoraca uglavnom vode dokumentaciju o pomorcima u vlastitim bazama podataka. No, često se događa da u tim bazama podataka agenti nemaju pomorce s traženim časničkim zvanjima ili zvanjima pomoćnog osoblja, odnosno događa se da agencije utroše mnogo vremena na pronalazak željenog kadra koji posjeduje tražene kvalifikacije i iskustvo. Stoga su, u ovom radu, istražene pozitivne i negativne strane zajedničke baze podataka pomoraca, njihova svrsishodnost ili manjkavost te stavovi agencija za posredovanje pri zapošljavanju pomoraca o zajedničkim bazama podataka. Provedeno je istraživanje i anketa među agencijama za posredovanje pri zapošljavanju pomoraca u svrhu dobivanja osnovnih informacija o poslovanju agencija i njihovim stavovima o zajedničkoj bazi podataka pomoraca.

Ključne riječi: baze podataka, pomorci, agenti posrednici pri zapošljavanju pomoraca, dokumenti pomoraca 